\title{
Introduction: Current Directions in Community Archaeology of the African Diaspora
}

\section{Camille Westmont ${ }^{1}$ (D) Elizabeth Clay $^{2}$}

Accepted: 21 August 2021 / Published online: 10 September 2021

(c) The Author(s), under exclusive licence to Springer Science+Business Media, LLC, part of Springer Nature 2021

\begin{abstract}
This article introduces the special issue, "Community Archaeology of the African Diaspora." This collection of papers grew out of a session at the 2020 Society for Historical Archaeology conference in Boston, Massachusetts, with additional authors invited to add further geographical and methodological diversity. The papers in this issue address a single question-how are archaeologists currently involved with community archaeology projects related to the African Diaspora?-and reflects the wide array of approaches currently being implemented across the discipline.
\end{abstract}

Keywords African diaspora $\cdot$ Community archaeology $\cdot$ Heritage $\cdot$ Collaborative archaeology

\section{Introduction}

Archaeology, with its unique insights into marginalized and forgotten communities, has a leading role to play in promoting greater recognition, both historically and in the present day, of multiethnic and multiracial histories. This special issue explores how archaeologists working in communities today are fostering that recognition, both through confronting the stories and monuments that continue to marginalize members of the African Diaspora and through generating new stories and monuments where recognition is sorely lacking. Through careful and deliberate actions that seek to empower communities, this collection of articles presents a glimpse into some of the work being done as part of the community archaeology of the African Diaspora.

V. Camille Westmont

vcwestmont@gmail.com

1 Center for Southern Studies, University of the South, 735 University Avenue, Sewanee, TN 37373, USA

2 Department of Anthropology, University of Pennsylvania, 3260 South Street, Philadelphia, PA 19104, USA 
As the United States continues to reel from deaths of African Americans at the hands of police and activists globally stand against racism and white supremacy in their own communities, the role that history, heritage, and commemoration play in perpetuating inequalities has become clear. As statues of slave traders, colonizers, and Confederate generals continue to be protested and removed, and projects aiming to expose the depths of America's history of enslavement and racial violence have gained traction in popular culture, the time to act is now. Representation requires an identity to represent, and identity needs a narrative in which we "locate ourselves and are located in" (Anico and Peralta 2009:1). When done correctly, archaeology provides a narrative in which stories and identities can evolve. The articles in this volume explore some of the ways historical archaeologists are pursuing new stories, new perspectives, and new voices through community archaeology.

The majority of the papers in this volume are derived from the 2020 Society for Historical Archaeology conference symposium titled, Community Archaeology in 2020: Conventional or Revolutionary?, held in Boston, Massachusetts. Although the session itself was broadly construed, a distinct cohort of papers focused on the community archaeology of Black and African American groups emerged, suggesting the immediacy and timeliness of this form of inquiry. These papers span the breadth of community archaeology practices in the present moment, from the challenges of setting up collaborative projects to the barriers to working in developing contexts to the actions archaeologists are taking to change both the discipline and the archaeological status quo. In the vein of other recent scholarship on both the theory and praxis of African Diaspora archaeology (e.g., Blakey 2020; Franklin et al. 2020; Lee and Scott 2019; White and Fennell 2017), this volume seeks to not just present current projects but to push forward with a vision for what may be possible. In this introduction, we review the origins of community archaeology and African Diaspora archaeology and current trends within both fields. We then provide an overview of the projects and scholarship collected in this volume. We round out the introduction with some of our own observations and considerations of the challenges inherent to community archaeology in its many forms, including balancing the needs and desires of stakeholders, sustainability, and the well-meaning but potentially harmful impacts community archaeology can have on the public.

\section{Community Archaeology of the African Diaspora: Conventional or Revolutionary?}

Any discussion of public and community archaeology must necessarily begin with a contextualization of the terms. Merriman (2004) observes that the emergence of a "public" archaeology in the 1970s was an implicit acknowledgment of the increasing professionalization of the field and the concomitant decline of public participation in "regular" archaeology. In the US context, McGimsey's (1972) book, Public Archaeology, was the first to examine the role that non-specialists played in managing archaeological assets; while the book has received this and similar appellations from dozens of public archaeologists, its vision of where archaeological activity "had the potential to interact with the public" (Schadla-Hall 1999:147) was limited 
mainly to legislation and archaeology carried out "in the public interest" (Merriman 2004:1). Public archaeology as it is practiced today largely emerged in the 1980s and extends far beyond those early conceptions, with a multitude of publics, communities, stakeholders, and collaborative practices (Ayan-Vila and Gonzalez-Ruibal 2014; Moshenska 2009; Schadla-Hall 1999). Ethics, in particular, have become a primary concern in both the manner of interaction and the formulation of the project (McDavid and Brock 2015). In this way, public archaeology is increasingly the "product of self-scrutiny" as public archaeologists attempt to reckon with the contemporary cultural, political, and economic trends that shape the power relations embedded within archaeological practice (Matsuda 2004: 67). In this issue, we embrace public archaeology through the application of community archaeology.

Community archaeology is often recognized as a subset of public archaeology, one that incorporates multivocality and collaborative practices to some degree (McDavid and Brock 2015). Definitions of community archaeology are continuously debated in the literature (Corbishley 2011; Marshall 2002; Moshenska and Dhanjal 2012; Thomas 2010, 2017; Waterton and Smith 2010), as are questions as to what constitutes a community (Agbe-Davies 2010; Simpson 2010; Smith and Waterton 2009). Foundational scholarship on community archaeology situates its emergence within a reflexive and politically aware turn that, along with Indigenous and postcolonial archaeologies, emphasizes the importance of collaboration with community members or "stakeholders" in investigations of the past (Moser et al. 2002; Tully 2007). The incorporation of non-archaeologists who, in theory, identify with a given project in the process of archaeological analysis and interpretation inherently introduces a multivocal perspective. However, community collaborations can be profoundly transformative for archaeology and archaeologists.

Community archaeology has played a prominent role in spurring and supporting local social movements. The increasing recognition that top-down archaeology disenfranchises communities and harms descendant groups has resulted in calls to promote more community-centered work (McAnany and Parks 2012; Pyburn 2014). In the last 50 years, a raft of projects have sought to do precisely this through intentional, coordinated, and collaborative plans that aim to elevate and transform traditional approaches to archaeology by emphasizing community needs (Atalay et al. 2014). In some instances, such as in Alexandria, Virginia, communities have established bureaucratic institutions to enshrine their right to participate in their community archaeology (Appler 2015). In others, archaeologists have taken it upon themselves to engage communities in ways that seek to use archaeology as a tool for modern social activism (Atalay et al. 2014; Silverman and Ruggles 2007; Stottman 2010; Westmont and Antelid 2018). With its demonstrated ability to provide new perspectives for confronting social problems, community archaeology offers a path forward for civically engaged, community-based work focused on the African Diaspora.

All archaeology is political, and community archaeology, with its resurfacing of potentially dark histories, is especially so (Ayan-Vila and Gonzalez-Ruibal 2014). Rooted in the Civil Rights movement of the 1960s, the archaeology of the African Diaspora represents not just greater visibility of African American history but an active engagement with the racial politics of archaeology as a whole (Blakey 2020; 
Lee and Scott 2019). African Diaspora archaeology has "contributed to the growth of an active community of scholars-both of African and European descent-eager to align their scholarship and professional training with the concomitant goals of decolonizing anthropology and challenging race, class, and gender oppression through archaeology" (Lee and Scott 2019: 85; see also Agbe-Davies 2007; Franklin and McKee 2004; Singleton and Bograd 1995). However, undertaking such projects requires a truthful accounting of the past that can be hurtful for communities in the present, such as the legacies of slavery and ongoing racial segregation (Haviser 2015).

While archaeologists studying plantations made an early shift in focus away from elite whites and toward enslaved African populations, it was not until the growth of critical archaeology and the passage of the Native American Graves Protection and Repatriation Act (NAGPRA) — both in the 1990s - that calls to bring community stakeholders into research projects became commonplace. Archaeologists of color led the critique that the study of the African Diaspora was undertaken almost exclusively by white scholars (Franklin 1997; Singleton 1995). Engagement with critical theory called for self-reflexivity about the consequences of research within contemporary social contexts (Leone et al. 1987; Potter 1991). The push for reflection about the nature and relevance of archaeology generally and the specific call for greater involvement by descendant communities coincided with the discovery of the African Burial Ground in NYC, which illustrated to archaeologists the necessity of incorporating public and descendant groups in their projects-and the dangers of failing to do so. After demands for recognition, a cross-section of New York's African American community became collaborators in directing the course of the project (LaRoche and Blakey 1997). Public education and outreach became major components of the work after descendant and local community groups successfully lobbied for greater authority within the profession.

The archaeology of the African Diaspora continues to develop both methodologically and theoretically. Methodologically, scholars have applied new and prevailing trends in cutting-edge archaeology to African Diaspora sites, including digital reconstructions (Gonzalez-Tennant and Gonzalez-Tennant 2016), ancient DNA analyses (Schablitsky et al. 2019), and close considerations of material culture (AgbeDavies 2017; Franklin 2020; Sattes et al. 2020), many of these being comparative studies enabled by the growth of the Digital Archaeological Archive of Comparative Slavery (DAACS) (Galle et al. 2019). In general, the development of African Diaspora archaeology has been characterized by expansion in terms of the types of sites being studied, their geographical location, and who does and is included in research. While methods become increasingly interdisciplinary, theoretical work around the archaeology of the African Diaspora continues to evolve. Most pressingly, historical archaeologists have pursued decolonizing (Engmann 2019; Gonzalez-Tennant 2014) and anti-racist archaeological practices (Carey 2019; Franklin et al. 2020; Minkoff et al. forthcoming; Mullins 2008).

Although archaeologists continue to be predominantly white (Agbe-Davies 2007; Odewale et al. 2018), recent developments such as the founding of the Society for Black Archaeologists (SBA) in 2011 (Flewellen and Dunnavant 2012), an increasing number of archaeological projects focused on sites related to peoples of African 
descent (Agbe-Davies 2002), dedication to Black community partnerships (National Summit on Teaching Slavery 2019; Reeves 2004), and intentional actions by archaeologists to recruit more people of color into the discipline (see Flewellen et al., 2021; Minkoff et al. forthcoming) demonstrate a commitment to a more diverse field of practitioners.

Because "engagement" can take many forms, quantifying success or failure is difficult. To that end, the National Summit for Teaching Slavery, with support from the National Trust for Historic Preservation's African American Cultural Heritage Action Fund and the JPB Foundation, developed guidelines for engaging descendant communities in the interpretation of slavery (National Summit on Teaching Slavery 2019; available at: https://digitaldoorway.montpelier.org/project/national-summit-on-teaching-slavery/). While this work was initially developed as a means for assessing museums' and historic sites' inclusion of descendant communities in the ways they present and discuss enslavement, we believe the rubric can apply to many community archaeology projects, too. This offers a way for projects and institutions both to self-evaluate and to make community engagement initiatives legible across multiple sites and projects.

\section{Contributors to the Thematic Issue}

All the papers contributed here have been written during or shortly after the immense global social upheaval sparked by the murders of George Floyd, Breonna Taylor, and other African Americans at the hands of police in the United States, which has led to calls for recognition of the long history of Black and Afrodiasporic marginalization and oppression across the globe. The papers in this collection respond to these events to varying degrees; however, their focus on Afrodiasporic communities-either historical or contemporary-is itself a political act. In this respect, we provided the authors with as much space and autonomy as possible in which to express their personal views in the way they intended. Because of this editorial choice, the reader might notice variations throughout the issue with regard to the capitalization of terms. Know that these grammatical decisions are not errors, but intentional choices made by individual authors in the furtherance of political goals.

The papers naturally break down into two groups based on geography: those centered on US contexts and those located in the Caribbean and South America. The papers within this volume move from north to south across the North and South American continents. However, the papers also largely follow three tracks: those that examine the practical aspects of incorporating the disparate voices of the African Diaspora into broader historical narratives through collaborative public archaeology, those that use archaeology as a tool for civic and social engagement around pressing modern problems, and those that challenge current social structures, whether in archaeology specifically or in society more generally.

The volume begins with a reflection by Jeffrey Burnett (2021) on the challenges of starting new community-driven collaborations in Oak Bluffs, Massachusetts. He describes the process of establishing relationships with community members and 
organizations working to preserve African American heritage in the historic resort town. Situating his approach to working with communities within Black feminist scholarship, Burnett hopes to build off these relationships to create a communitybased participatory project in which archaeological research can make a productive contribution to local efforts already underway. The author notes the importance of acknowledging that an archaeological project can take many forms and that excavation may not ultimately fit within the parameters of a community heritage project.

Burnett's focus on incorporating stakeholder and descendent voices into the archaeological process is shared by Reid (2021) and White (2021). Rooted in archaeological ethics, multivocal archaeology can promote tolerance and an appreciation of diversity in society, both past and present (Little 2012). Although some have noted that collaborative and multivocal public projects do not necessarily dismantle power structures entirely (McDavid and Brock 2015), these papers demonstrate the power that community partnership can have in achieving community goals.

At Jamestown, archaeologists are using oral histories from the local African American community to decolonize the site's "whitewashed" historical narrative. Reid (2021) identifies a long history of privileging whiteness in the historical interpretations at Jamestown, effectively rendering it a "white public heritage space" that normalizes whiteness while controlling access to resources. The Angela Site, which was first excavated by a group of African American Civilian Conservation Corps (CCC) workers in the 1930s and is today recentering historical interpretations around the experiences of one of the first African women to arrive in the colony in 1619 , provides an opportunity to reconstruct erased histories and critically challenge the power relations embedded in who creates history. This project's incorporation of descendant voices acts as a powerful medium for complicating our current understandings of American history.

Looking to South America, White (2021) examines the challenges of conducting community archaeology projects in developing countries. Drawing on her own experiences working with Maroon communities in Suriname, White outlines how developing countries often lack the archaeological infrastructure needed to follow US or UK public archaeology models and therefore need to follow different approaches in order to ensure that descendant communities are included in archaeological research. White describes the wide variety of tools for community engagement that she has implemented in her participatory research with Maroons in Suriname and outlines how these could offer an alternative to untenable public archaeology models.

This work is important for its obvious potential for expanding inclusive archaeological practices to developing nations; however, in this instance, White highlights the stakes of this type of research. In contexts where heritage claims can affect communities' land rights, human rights, and/or sustainable development, working with descendant communities must take on a new degree of thought and intentionality. We are once again reminded that archaeology_including public archaeology-is political and can have real-world consequences for stakeholder communities, particularly descendent communities within the African Diaspora.

Two papers, both from the US, incorporate civic engagement into their community archaeology practice in ways that aim to serve modern Black communities. Little (2007:2) observes that "meaningful historical awareness coupled with varying 
degrees of empowerment can develop" when archaeology is used to make a difference in the lives of communities. While each paper approaches this concept from different angles, Jenkins (2021) and Westmont (2021) illustrate the possibilities engendered by civically and socially engaged community archaeology projects.

Jenkins' work in Easton, Maryland sees community archaeology mobilized in the service of a neglected historic African American neighborhood. Invited by an active group of local preservationists, community archaeology helped to raise the profile of the maligned neighborhood, empower its citizens through a redefined historical narrative, and prevent displacement-through-gentrification. The collaboration between the Hill and Archaeology in Annapolis demonstrates the social value archaeology can provide through the targeted use of archaeological products. In this case, community archaeology not only increased "political capital and local pride" within the African American community but has also played a prominent role in advocacy for community revitalization and preservation (Jenkins 2021).

Citing COVID-19 restrictions and an ongoing effort to identify descendent communities, Westmont (2021) engages with a different type of community: the local descendants of those who financially benefited from the forced labor of primarily Black convicts under the Southern convict lease system. By firmly establishing the convict leasing system as dark heritage, Westmont aims to nullify the site as a space for modern white supremacists and build empathy for the historical and modern incarcerated Black population. Through archaeological tours, Westmont demonstrates how the history of convict leasing at the Lone Rock Stockade set the stage for modern racialized incarceration as enabled by the 13th Amendment. Westmont uses surveys to chart local attitudes towards the site and its history in her effort to make the space safer for descendants of color to get involved with the project in the future. Although the region continues to experience racial strife, Westmont aims to use archaeology and an honest accounting of the past to promote a more racially inclusive and socially engaged perspective of the past and the present.

Flewellen, Odewale, Dunnavant, Jones, and White (2021) introduce the collaborative efforts of the Estate Little Princess Archaeological Project (ELPAP) on St. Croix. The authors interpret community archaeology not only in terms of an archaeology that benefits local communities by focusing on understudied aspects of island history but also by framing themselves as a community of scholars. As a team of Black archaeologists, ELPAP co-organizers crafted the project to enhance their development as junior scholars in a profession dominated by whiteness and notions of individualism. With this grounding in their own research community, including the broader Society of Black Archaeologists (SBA), the authors use the excavation at the Estate Little Princess to offer archaeological training free of charge to AfroCrucian youth and undergraduates from Historically Black Colleges and Universities in the US, thereby building capacity both locally in heritage management and increasing representation in the broader field of archaeology. ELPAP furthermore builds community laterally with other local organizations that focus on history and conservation. The authors frame their discussion in reference to Indigenous archaeologies by emphasizing that legal protections and government recognition-such as those provided through NAGPRA - are not in place for African Diaspora heritage sites. 
The community-engaged project in French Guiana (Guyane), Archéo La Caroline: Lavi nou Gangan [The Lives of Our Ancestors], was developed around the excavation in the village for enslaved laborers at the nineteenth-century plantation, Habitation La Caroline. This is the first excavation in this French overseas department to explicitly focus on the archaeology of enslaved Africans in a region where community archaeology is uncommon. Clay (2021) contextualizes the broader project within plantation tourism and archaeology in the U.S. and Caribbean to consider how archaeology and heritage have typically been managed in this region. She presents the structured site visit as a methodology for introducing Afro-Guianese people — as a descendant community broadly defined - to archaeology. This element of Archéo La Caroline aims to increase public access to archaeology as a first step toward building community engaged initiatives in the region.

While Clay focuses on the broad Guianese community of African descent, Hartemann (2021) describes more localized efforts at community engagement with residents of Wayam, an Indigenous settlement adjacent to Habitation La Caroline, and the Afro-Guianese residents of Roura, the nearest incorporated town. Hartemann discusses the results of memory conversations and memory walks with elders from both separate yet interrelated communities, discussions which are heavily focused on the resonance of archaeological materials for addressing the collective wounds imposed and continually reimposed by colonialism. They couch these efforts within the framework of Griotic archaeology, a decolonial praxis centered on grappling with epistemic violence within archaeology. This methodology is deeply connected to the author's personal identity and scholarly commitments to non-Western forms of knowledge production.

Both of the above projects are focused on changing systems. The Estate Little Princess Archaeological Project approaches community archaeology from a multiscalar perspective aiming not only to prioritize community interests but to confront systemic problems in the field by increasing representation. In French Guiana, Clay and Hartemann work to change how the public interacts with archaeology within a framework where this field is overseen by the state and African Diaspora archaeology has thus far been nonexistent. Each author approaches the efforts of their cocreated community-engaged project Archéo La Caroline: Lavi nou Gangan to collaborate with overlapping local communities. The positionality of each author is reflected in their separate perspectives on their shared project.

The papers in this collection demonstrate that there's no "one size fits all" model for community archaeology, especially when focused on marginalized populations (Thomas 2019). Instead, doing community work is highly contextual: projects that are responsive to local politics and community concerns are likely to be more meaningful and impactful.

\section{Negotiating Stakeholders and Ensuring Sustainability}

The papers in this collection illustrate two of the challenges inherent to any community archaeology project, but perhaps especially to projects related to the African Diaspora, including: negotiating multiple stakeholders and sustainability. The 
unique circumstances of each collaboration make standardization within community archaeology nearly impossible and, more pressingly, likely irrelevant. This makes community archaeology projects not only more difficult to implement, but more difficult to sustain.

One obstacle to the implementation of a consistent or standard approach to community archaeology is the varied needs of the community served through these types of projects. As the papers in this volume show, stakeholders can range from dispersed descendant groups to entire geographical communities and can include non-profit organizations and local governments. What is consistent across these projects, however, is the fact that each of these stakeholders will often have different needs, different perspectives, and different political ends (Mullins 2007; Pyburn 2011). These differences can make balancing the needs of multiple stakeholders both complicated and, at times, fraught. In the case of Afrodiasporic communitiescommunities that have frequently been overlooked or intentionally excluded from decision-making positions within archaeology-ensuring that community archaeology is pursuing community needs is not only good archaeological practice but can be considered within the discourse of human and civil rights, recognizing people's inalienable right to their culture (Nilsson Stutz 2008).

A second continuous problem for both the projects in this volume as well as community archaeology more generally is the issue of sustainability. In areas with few homegrown archaeologists, the structural divide between trained archaeologists and community members becomes starker. Projects lacking local frameworks and leadership will not be sustainable. When the archaeologist is also not a member of or permanent resident in a community, their role as an outside scholar is continually reinforced, further impeding collaboration and sustainability.

Beresford (2019:42) observes that archaeologists often institute a "back-to-front approach" to community work. This approach hobbles the potential for project sustainability by creating projects that the community can participate in rather than projects the community can (eventually) lead itself. Although "there are numerous projects that allow the public to dig, or field walk, or undertake landscape surveys, [there are] very few that teach how to compile funding bids to fund that work, or how to digitize drawings, or write-up a test pit, or compile a project report." As archaeologists expose members of the public to an increasingly limited set of activities, they run the risk of inadvertently defining public archaeology as digging holes with volunteers (Simpson and Williams 2008). In short, a sustainable community archaeology project is one that teaches community members how to carry out all aspects of the archaeological process, including the mundane and tedious aspects. Despite the need to build capacity, in some cases, communities may not be interested in learning how to do archaeology but may instead want to be involved in developing research questions or simply be made aware of the findings. In this case, the archaeologist might share power in terms of making research transparent but would still use their skills for the benefit of communities. Therefore, being responsive to local needs becomes essential and will again require that archaeologists understand the various stakeholders involved in any project.

The question of sustainability in community archaeology is not trivial: failure to plan long-term can harm communities when the project is over and the funding 
has run out, leaving community members with nothing to show for the effort. On the other hand, projects that foster sustainability transform enthusiasm into genuine understanding and care for history (Belford 2014:27). Sustainable projects help participants develop skills, promote more in-depth engagement with the materials, create lasting personal impacts among participants, and increase the success and overall value of the project (Moshenska et al. 2011:97-98). If done well, sustainable community archaeology can promote social, economic, and intellectual sustainability (Belford 2014); however, structural challenges also present hurdles to project longevity. Community archaeology projects require funding, which is increasingly more difficult to secure as funding sources in general contract and research support for the humanities and social sciences becomes especially scarce. Without funding (or the know-how to obtain funding), projects risk defaulting.

\section{A Methodological Reckoning?}

In addition to the challenges discussed above, archaeologists leading communitybased participatory research (CBPR) projects are also likely to encounter difficulties related to power sharing. Although power sharing, in theory, has become a central tenet of decolonized community archaeology (Atalay 2012), in practice, it continues to be challenging to implement successfully (La Salle 2010). Many scholars, particularly those working with Indigenous communities, have already observed that imposing Western research models onto archaeological projects perpetuates colonial attitudes and settler-based power structures and inequalities (La Salle 2010; Supernant and Warrick 2014; White Deer 1998). However, innumerable structural barriers continue to prevent "pure" collaboration or collaborations in which archaeological praxis and archaeologist involvement are truly decolonized. These barriers range from differential access to funding and governmental permits required to carry out archaeological work to the inherent colonial biases embedded in the very foundations of archaeological epistemologies. These structural asymmetries are even more difficult to reconcile because those not marginalized by them often have difficulty realizing they exist at all (Trigger 1980).

Others proffer a potentially more insidious view of archaeological collaboration. This faction suggests that public archaeology is not just a well-meaning attempt to connect with stakeholder communities, but part of a larger attempt to preserve archaeology as a discipline. In this "public relations" model of archaeology, we understand public archaeology as a method to improve the public image of the field while building political and economic support for it (Holtorf 2007; Matsuda 2016; see Belford 2014). Dawdy (2009:137) observes that the language of archaeological collaboration mirrors that of marketing, raising the possibility that collaboration and power sharing are actually "oriented towards smoothing the way so archaeologists can placate a potentially troublesome public and still go about their business." Dawdy (2009:137-138) goes on to suggest that "the [primary] aim is to bolster the public support of archaeology so that the laws stay on the books and the money keeps flowing... Archaeology has been very useful lately, but primarily to itself." While this statement is undeniably edgy, Dawdy (2009:137) demonstrates the 
truth within it: "If your children need better public schools, are you going to turn to archaeology as a solution? If your community is strained with racial tensions, is archaeology the solution?" While archaeology has been shown to have positive outcomes for communities, as archaeologists, we need to ensure that our work is genuinely rooted in pragmatism and communities' real-world circumstances-circumstances where archaeology might be a distraction rather than an actual fix. Whether promoting the field (and our careers) is a primary aim or not, archaeologists who work with the public should be constantly aware of the benefits we receive from engaging in community collaborations and do the utmost to ensure that we are not the only ones to benefit from these arrangements.

In some sense, the inclusion of professional archaeologists-archaeologists trained in predominantly white Western academies in the predominantly white Western traditions of archaeology - is an injection of colonial bias into the process through the simple fact that archaeologists cannot separate themselves from the systems of knowledge they were indoctrinated into during the process of becoming archaeologists (see Hill 2006; Peters 2006). While archaeologists often mean well in their efforts to transfer power to communities, even when successful, these attempts fail to address the deeper Western biases within the field, including its emphases on materiality and demands for conservation. While CBRP is an important step in working toward equality with stakeholder and descendant communities, the power inequalities inherent within archaeology as practiced in the Western world will never be solved solely by collaboration. Equality does not inherently mobilize selfdetermination, self-representation, or sovereignty (La Salle 2010). At the end of the day, the archaeologist associated with the project is usually still required to fulfill the standard archaeological paperwork, rendering community control a veneer over a stubbornly inflexible system that continues to privilege the archaeologist as the one with real power. Furthermore, if capacity building efforts transfer these skills to communities, this may simply serve to reproduce the power imbalances inherent to archaeological research. While multiple scholars have called for the field to reckon with its past and "transform" itself from the ground up (Atalay et al. 2014; Martindale and Lyons 2014), until these and related considerations can be fully addressed, community archaeology, as well as archaeology as a whole, will continue to suffer from degrees of inequality and exploitation between archaeologists and communities.

In the absence of any methodological reckoning with the entire field of archaeology, a key consideration arises: are there instances where archaeologists should intervene? While scholars continue to push for increased community control, the potential for archaeologists' power to be used in productive ways to mediate claims to the past has been sidelined. Archaeologists' role as authorities over archaeological methods and sites can be marshaled in a variety of different ways that ultimately benefit communities, including by creating safe spaces within otherwise antagonistic environments and by amplifying marginalized communities' interpretations over those proffered by socially dominant factions. This can be particularly important when working with Afrodiasporic communities within white supremacist contexts, as our own projects demonstrate. Westmont's work at the Lone Rock Stockade has shown that archaeologists can draw on their own identity politics to fight ideological 
battles against groups that seek to marginalize African Americans, thereby sparing African American descendant groups additional trauma while forcing white people to do their own work to correct racist ideas. In French Guiana-where the majority of archaeological projects are conducted by white scholars primarily for a white public-Clay uses her position to incorporate communities of color by creating targeted opportunities for engagement. These not only expose Afrodiasporic groups to the field of archaeology but highlight the experiences of enslaved people to counter the colonial narratives of other regional projects. In this sense, archaeologists can help minority communities "carry the load" of societal racism, at least with regard to archaeological and heritage sites.

\section{Conclusion}

Community archaeology always has and likely always will require a delicate balance between community needs, archaeologist involvement, and project goals. As community archaeologists working within contexts related to current and/or historic populations of the African Diaspora, the stakes of our community research could not be higher. While we continue to refine and develop our methods for working collaboratively, for supporting communities, and for creating sustainable projects, we also need to be constantly aware of the ways in which our work can inadvertently perpetuate power imbalances. While the articles in this issue begin to take us in this direction through their varied approaches to the general topic of African Diaspora community archaeology, they also demonstrate the challenges that remain: how do we truly decolonize archaeology, down to the level of our methods? How do we ensure our primary motivations are the wellbeing of communities, not our own careers or research questions? How do we rebuild the trust lost through so many mismanaged projects and mishandled public outreach efforts? While we cannot address these questions quite yet, we believe the papers in this volume represent organic attempts to bridge the structural divides between archaeologists and communities of color in fruitful and beneficial ways.

\section{References}

Appler, D. R. (2015). The formation of the Alexandria Archaeological Commission: connecting citizen activism, archaeology, and local government in Alexandria, Virginia. Journal of Community Archaeology and Heritage 2(1): 22-39.

Atalay, S. (2012). Community-Based Archaeology: Research With, By, and For Indigenous and Local Communities. University of California Press, Berkeley.

Atalay, S., Clauss, L. R., McGuire, R., and Welch, J. R. (eds.) (2014). Transforming Archaeology: Activists Practices and Prospects. Left Coast Press, Walnut Creek, CA.

Agbe-Davies, A. S. (2002). Black scholars, Black pasts. SAA Archaeological Record 2(4): 24-28.

Agbe-Davies, A. S. (2007). Practicing African-American archaeology in the Atlantic World. In Ogundiran, A. and Falola, T. (eds.), Archaeology of Atlantic Africa and the African Diaspora. Indiana University Press, Bloomington, pp. 413-425.

Agbe-Davies, A. S. (2010). Concepts of community in the pursuit of an inclusive archaeology. International Journal of Heritage Studies 16(6): 373-389. 
Agbe-Davies, A. S. (2017). Where tradition and pragmatism meet: African diaspora archaeology at the crossroads. Historical Archaeology 51: 9-27.

Anico, M. and Peralta, A. (2009). Introduction. In Anico, M. and Peralta, A. (eds.), Heritage and Identity: Engagement and Demission in the Contemporary World. Routledge, London, pp. 1-12.

Ayan-Vila, X. and Gonzalez-Ruibal, A. (2014). "Public" and archaeology. In Smith, C. (ed.), Encyclopedia of Global Archaeology. Springer, New York, pp. 6197-6202.

Belford, P. (2014). Sustainability in community archaeology. AP: Online Journal in Public Archaeology, Special Volume 1: 21-44.

Beresford, M. (2019). "Dig Society": funding models and sustainability in community archaeology. In Williams, H., Pudney, C., and Ezzeldin, A. (eds.), Public Archaeology: Arts of Engagement, Archaeopress, Oxford, pp. 41-52.

Blakey, M. L. (2020). Archaeology under the blinding light of race. Current Anthropology 61(supplement 22): S183-S197.

Burnett, J. J. (2021). Seeking radical solidarity in heritage studies: exploring the intersections of Black feminist archaeologies and geographies in Oak Bluffs, MA. International Journal of Historical Archaeology. https://doi.org/10.1007/s10761-021-00601-y

Carey, M. L. (2019). Toward an antiracist archaeology. Activist History Review. www.activisthistory.com/ 2019/09/27/toward-an-antiracist-archeology/

Clay, E. C. (2021). Mo té la: building community-engaged plantation archaeology in Guyane. International Journal of Historical Archaeology. https://doi.org/10.1007/s10761-021-00625-4

Corbishley, M. (2011). Pinning Down the Past: Archaeology, Heritage, and Education Today. Boydell, Woodbridge.

Dawdy, S. L. (2009). Millennial archaeology: locating the discipline in the age of insecurity. Archaeological Dialogues 16(2): 131-142.

Engmann, R. A. A. (2019). Autoarchaeology at Christiansborg Castle (Ghana): decolonizing knowledge, pedagogy, and practice. Journal of Community Archaeology and Heritage 6(3): 204-219.

Flewellen, A. and Dunnavant, J. (2012). Society of Black Archaeologists. African Diaspora Archaeology Newsletter. Spring. http://www.diaspora.illinois.edu/news0312/news0312.html

Flewellen, A., Odewale, A., Dunnavant, J., Jones, A., and White W. A., III. (2021). Creating community and engaging community: the foundations of the Estate Little Princess Archaeology Project. International Journal of Historical Archaeology. https://doi.org/10.1007/s10761-021-00600-z

Franklin, M., Dunnavant, J. P., Flewellen, A. O., and Odewale, A. (2020). The future is now: archaeology and the eradication of anti-Blackness. International Journal of Historical Archaeology 24(4): 753-766.

Franklin, M. (1997). "Power to the people": sociopolitics and the archaeology of Black Americans. Historical Archaeology 31(3): 36-50.

Franklin, M. (2020). Enslaved household variability and plantation life and labor in colonial Virginia. International Journal of Historical Archaeology 24: 115-155.

Franklin, M. and McKee, L. (2004). African Diaspora archaeologies: present insights and expanding discourses. Historical Archaeology 38: 1-9.

Galle, J. G., Bollwerk, E., and Neiman, F. D. (2019). The Digital Archaeological Archive of Comparative Slavery: a case study in open data and collaboration in the field of archaeology. In Allen, R. and Ford, B. (eds.), New Life for Archaeological Collections. University of Nebraska Press, Lincoln, pp. 55-90.

Gonzalez-Tennant, E. (2014). The "color" of heritage: decolonizing collaborative archaeology in the Caribbean. Journal of African Diaspora Archaeology and Heritage 3(1): 26-50.

Gonzalez-Tennant, E. and Gonzalez-Tennant, D. (2016). The practice and theory of new heritage for historical archaeology. Historical Archaeology 50(1): 186-203.

Hartemann, G. O. (2021). Unearthing colonial violence: Griotic archaeology and community-engagement in Guiana. International Journal of Historical Archaeology. https://doi.org/10.1007/ s10761-021-00596-6

Haviser, J. B. (2015). Truth and reconciliation: transforming public archaeology with African descendant voices in the Dutch Caribbean. Journal of African Diaspora Archaeology and Heritage 4(3): 243-259.

Hill, R. W. (2006). Making a final resting place final: a history of the repatriation experience of the Haudenosaunee. In Kerber, J. (ed.), Cross-Cultural Collaboration: Native Peoples and Archaeology in the Northeastern United States. University of Nebraska Press, Lincoln, pp. 3-17. 
Holtorf, C. (2007). Archaeology is a Brand!: The Meaning of Archaeology in Contemporary Popular Culture. Archaeopress, Oxford.

Jenkins, T. H. (2021). Sustaining tangible neighborhood change through African American archaeology in Easton, Maryland: evaluating The Hill Community Project. International Journal of Historical Archaeology. https://doi.org/10.1007/s10761-021-00598-4

LaRoche, C. J. and Blakey, M. L. (1997). Seizing intellectual power: the dialogue at the New York African Burial Ground. Historical Archaeology 31(3): 84-106.

La Salle, M. J. (2010). Community collaboration and other good intentions. Archaeologies: Journal of the World Archaeological Congress 6(3): 401-422.

Lee, N. K. and Scott, J. N. (2019). Introduction: new directions in African Diaspora archaeology. Transforming Anthropology 27(2): 85-90.

Leone, M. P., Potter, P. B. Jr., Shackel, P. A., Blakey, M. L., Bradley, R., Durrans, B., Gero, J. M., Grigoriev, G. P., Hodder, I., Lanata, J. L., Levy, T. E., Silberman, N. A., Paynte, R., Rivera, M. A., and Wylie, A. (1987). Toward a critical archaeology [and comments and reply]. Current Anthropology 28(3): 283-302.

Little, B. J. (2007). Archaeology and civic engagement. In Little, B. J. and Shackel, P. A. (eds.), Archaeology as a Tool of Civic Engagement. AltaMira Press, Lanham, MD, pp. 1-27.

Little, B. J. (2012). Public benefits of public archaeology. In Skeates, R., McDavid C., and Carman, J. (eds), The Oxford Handbook of Public Archaeology. Oxford University Press, Oxford, pp. 395-413.

Marshall, Y. (2002). What is community archaeology?. World Archaeology 34(2): 211-219.

Martindale, A. and Lyons, N. (2014). Introduction: community-oriented archaeology. Canadian Journal of Archaeology/Journal Canadien d'Archéologie 38(2): 425-433.

Matsuda, A. (2004). The concept of "the public" and the aims of public archaeology. Papers from the Institute of Archaeology 15: 66-76.

Matsuda, A. (2016). A consideration of public archaeology theories. Public Archaeology 15(1): 40-49.

McAnany, P. A. and Parks, S. (2012). Casualties of heritage distancing: children, Ch'orti' Indigeneity, and the Copán archaeoscape. Current Anthropology 53(1): 80-107.

McDavid, C. and Brock T. P. (2015). The differing forms of public archaeology: where we have been, where we are now, and thoughts for the future. In Gnecco, C. and Lippert, D. (eds.), Ethics and Archaeological Praxis. Springer, New York, pp. 159-183.

McGimsey, C., III (1972). Public Archaeology. Seminar, New York.

Merriman, N. (2004). Public Archaeology. Routledge, London.

Minkoff, M. F., Brock, T. P., and Reeves, M. (forthcoming). Aiming for anti-racism: policies and practices of a publicly engaged archaeology department. In Westmont, V. C. (ed.), Critical Public Archaeology . Berghahn, New York

Moser, S., Glazier, D., Philips, J., El Nemer, L. N., Mousa, M. S., Richardson, S., Conner, A. and Seymour, M. (2002). Transforming archaeology through practice: strategies for collaborative practice in the community archaeology project at Quseir, Egypt. World Archaeology 34(2): 220-248.

Moshenska, G. (2009). What is public archaeology? Present Pasts 1: 46-48.

Moshenska, G. and Dhanjal, S. (2012). Introduction: thinking about, talking about, and doing community archaeology. In Moshenska, G. and Dhanjal, S. (eds.), Community Archaeology: Themes, Methods and Practices. Oxbow, Oxford, pp. 1-5.

Moshenska, G., Dhanjal, S., and Cooper, C. (2011). Building sustainability in community archaeology: the Hendon School Archaeology Project. Archaeology International 13/14: 94-100.

Mullins, P. R. (2007). Politics, inequality, and engaged archaeology: community archaeology along the color line. In Little, B. J. and Shackel, P. A. (eds.), Archaeology as a Tool of Civic Engagement. AltaMira Press, Lanham, MD, pp. 89-108.

Mullins, P. R. (2008). Excavating America's metaphor: race, diaspora, and vindicationist archaeologies. Historical Archaeology 42(2): 104-122.

National Summit on Teaching Slavery. (2019). Engaging descendant communities in the interpretation of slvaery at museums and historic sites. History News 74(1): 14-21.

Nilsson Stutz, L. (2008). Archaeology, identity and the right to culture: anthropological perspectives on repatriation. Current Swedish Archaeology 15-16: 157-172.

Odewale, A., Dunnavant, J., Flewellen, A., and Jones, A. (2018). Archaeology for the next generation. Anthropology News 59(1): e210-e215.

Orser, C. E. Jr. (2001). The anthropology in American historical archaeology. American Anthropologist 103(3): 621-632. 
Peters, R. L (2006). Consulting with the Bone Keepers: consultations and archaeological monitoring in the Wampanoag Territory. In Kerber, J. (ed.), Cross-Cultural Collaboration: Native Peoples and Archaeology in the Northeastern United States. University of Nebraska Press, Lincoln, pp. 32-43.

Potter, P. B. Jr. (1991). What is the use of plantation archaeology? Historical Archaeology 25(3): 94-107.

Pyburn, K. A. (2011). Engaged archaeology: whose community? which public? In Okamura, K. and Matsuda, A. (eds.), New Perspectives in Global Public Archaeology. Springer, New York, pp. 29-41.

Pyburn, K. A. (2014). Preservation as "disaster capitalism": the downside of site rescue and the complexity of community engagement. Public Archaeology 13(1-3): 226-239.

Reeves, M. B. (2004). Asking the "right" questions: archaeologists and descendant communities. In Shackel, P. A. and Chambers, E. J. (eds.), Places in Mind: Public Archaeology as Applied Anthropology. Routledge, New York, pp. 71-81.

Reid, L. C. (2021). "It's not about us": exploring white-public heritage space, community, and commemoration on Jamestown Island, Virginia. International Journal of Historical Archaeology. https://doi. org/10.1007/s10761-021-00593-9

Sattes, C. A. H., Marcoux, J. B., Platt, S. E., Zierden, M. and Anthony, R. W. (2020). Preliminary identification of African-style rouletted colonoware in the colonial South Carolina lowcountry. Journal of African Diaspora Archaeology and Heritage https://doi.org/10.1080/21619441.2020.1840837

Schablitsky, J. M., Witt, K. E., Madrigal, J. R., Ellegaard, M. R., Malhi, R. S. and Schroeder, H. (2019). Ancient DNA analysis of a nineteenth century tobacco pipe from a Maryland slave quarter. Journal of Archaeological Science 105: 11-18.

Schadla-Hall, T. (1999). Editorial: public archaeology. Journal of European Archaeology 2(2): 147-158.

Silverman, H., and Ruggles, D. F. (2007). Introduction: cultural heritage and human rights. In Silverman, H. and Ruggles, D. F. (eds.), Cultural Heritage and Human Rights. Springer, New York, pp. 3-29.

Simpson, F. A. (2010). The Values of Community Archaeology: A Comparative Assessment Between the $U K$ and $U S$. Archaeopress, Oxford.

Simpson, F. and Williams, H. (2008). Evaluating community archaeology in the UK. Public Archaeology 7(2): 69-90.

Singleton, T. A. (1995). The archaeology of slavery in North America. Annual Review of Anthropology 24: $119-140$.

Singleton, T. A. and Bograd, M. D. (1995). The Archaeology of the African Diaspora in the Americas. Society for Historical Archaeology, Tucson.

Smith, L. and Waterton, E. (2009). Heritage, Communities and Archaeology. Duckworth Academia, London.

Stottman J. (ed.). (2010). Archaeologists as Activists: Can Archaeologists Change the World?. University of Alabama Press, Tuscaloosa.

Supernant, K. and Warrick G. (2014). Challenges to critical community-based archaeological practice in Canada. Canadian Journal of Archaeology/Journal Canadien d'Archéologie 38(2):563-591.

Thomas, S. (2010). Community Archaeology in the UK: Recent Findings. Council for British Archaeology, York. https://tuhat.helsinki.fi/ws/portalfiles/portal/40303543/CBA_Report_2010.pdf. Accessed 1 Feb 2021.

Thomas, S. (2017). Community archaeology. In Moshenska, G. (ed.), Key Concepts in Public Archaeology. UCL Press, London, pp. 14-30.

Thomas, S. (2019). Doing public participatory archaeology with "difficult" conflict heritage: experiences from Finnish Lapland and the Scottish Highlands. Post-Classical Archaeologies 9: 147-167.

Trigger, B. G. (1980) Archaeology and the image of the American Indian. American Antiquity 45(4) $662-676$.

Tully, G. (2007). Community archaeology: general methods and standards of practice. Public Archaeology 6(3): 155-187.

Waterton, E. and Smith, L. (2010). The recognition and misrecognition of community heritage. International Journal of Heritage Studies 16(1-2): 4-15.

Westmont, V. C. (2021). Dark heritage in the New South: remembering convict leasing in southern middle Tennessee through community archaeology. International Journal of Historical Archaeology. https://doi.org/10.1007/s10761-021-00592-w

Westmont, V. C. and Antelid, A. (2018). The place to be: community archaeology as a tool for cultural integration. Journal of Community Archaeology and Heritage 5(4): 237-249.

White, C. (2021). Defining measures in community-based archaeology in Suriname. International Journal of Historical Archaeology. https://doi.org/10.1007/s10761-021-00620-9 
White, W. A., III and Fennell, C. C. (eds.) (2017). Challenging theories of racism, diaspora, and agency in African America. Historical Archaeology 51(1): 1-148.

White Deer, G. (1998). Return of the sacred: spirituality and the scientific imperative. In Whitley, D. S. (ed.), Reader in Archaeological Theory: Post-Processual and Cognitive Approaches. Routledge, New York, pp. 331-337.

Publisher's note Springer Nature remains neutral with regard to jurisdictional claims in published maps and institutional affiliations. 